\title{
PENGARUH PRODUK ATRIBUT PADA PERILAKU PELANGGAN ORGANISASI PADA PUTUSAN PEMBELIAN JASA PAKET MEETING (MICE) DI HOTEL MALYA-BANDUNG
}

\author{
Hasniati Halim \\ Dosen Prodi Bisnis Administrasi (Fakultas: Bisnis dan Komunikasi) \\ Universitas Swiss German \\ email : hasniati.halim66@gmail.com
}

\begin{abstract}
ABSTRAK
Manajemen Hotel Malya saat ini melakukan repositioning dengan menambah segmen market baru yaitu MICE business (Meeting, Incentive, Convention and Exhibition), sehingga diperlukan suatu upaya untuk memahami karakteristik pelangggan MICE tersebut dengan cara mengetahui besarnya pengaruh atribut produk terhadap sikap pelanggan corporate meeting di Hotel Malya Bandung. Analisis kuantitatif berupa analisis jalur dipergunakan untuk menghitung besarnya pengaruh atribut produk terhadap sikap pembelian pelanggan. Teknik pengumpulan data menggunakan teknik sensus dengan alat bantu kuestioner disebarkan kepada 50 perusahaan yang telah menyelenggarakan corporate meeting di hotel Malya pada periode tertentu, dengan menggunakan teknik judgment sampling. Hasil penelitian dan pengujian hipotesis pengaruh atribut produk terhadap sikap pembelian pelanggan dapat disimpulkan bahwa hanya People $\left(X_{3}\right)$ yang berpengaruh signifikan secara langsung terhadap sikap pembelian yaitu sebesar 35,40\%. Pengaruh Physical Evidence $\left(X_{1}\right)$ dan Process $\left(X_{2}\right)$ tidak berpengaruh signifikan terhadap sikap pembelian, namun berpengaruh tidak langsung melalui People $\left(X_{3}\right)$ yaitu sebesar 24.14\%. Sedangkan pengaruh lain terhadap sikap pelanggan yang tidak dipergunakan dalam penelitian ini yaitu sebesar 40,46\%. Dapat disimpulkan pula bahwa setiap perusahaan memiliki Unit Buying Center yang terbentuk secara informal tidak terstruktur dan sangat dinamis karena peran masing-masing orang dalam buying center berubah-ubah, hal ini menyebabkan pemasar perlu membuat strategi promosi yang efektif melalui aktifitas sales call (personal selling) yang tepat, sehingga manajemen perlu mengetahui aturan main yang diberlakukan ke masing-masing konsumen perusahaan untuk menggunakan pendekatan yang tepat.
\end{abstract}

Kata Kunci : sikap pelanggan organisasi, atribut produk, physical evidence, proses, orang, afektif, kepuasan

\section{PENDAHULUAN}

\section{Latar Belakang Masalah}

Perubahan dalam dunia bisnis merupakan hal yang harus dilakukan pelaku bisnis dalam mempertahankan keberadaannya dan beradaptasi dengan lingkungan yang terus berubah secara 
dinamis, yang dipicu oleh faktor-faktor: politik, ekonomi, sosial, teknologi yang secara langsung akan berpengaruh pula terhadap pasar (Caplow, 2013). Dinamika pasar inilah yang harus dipahami dan disikapi perusahaan dengan menyesuaikan dan merumuskan ulang strategi bisnisnya agar dapat bertahan dan dapat meraih keunggulan pasar. Salah satu upaya adalah dengan cara repositioning.

Repositioning yang telah dilakukan manajemen Hotel Malya adalah dengan menambah segmen market baru, yaitu MICE business, strategi ini sebagaimana yang ditulis oleh Robert L. Lewis \& Richard Chambers yang menyatakan bahwa: "Repositioning might also be used to appeal to a new segment, to add a new segment while trying to hold on to an old one, or to increase the size of a segment" (Chambers \& Lewis, 2015).

Tamu hotel dapat dikategorikan menjadi dua kelompok besar, yaitu pleasure dan business. Kelompok bisnis inilah yang termasuk dalam industri MICE atau Meeting industry disebut juga sebagai event business (Redor, 2016). Perbedaan ini tentu saja menimbulkan dua kebutuhan yang berbeda yang perlu diakomodir oleh pihak hotel. Atribut kritis untuk menjadi destinasi MICE adalah: (1) MICE facilities and lodging, (2) cost \& affordability, (3) leisure and entertainment facilities, (4) service \& professionalism, (5) infracstructure \& accessibility, (6) business-friendliness \& image, dan (7) government support (Nadkarni \& Leong, 2007).

Menimbang bahwa segmen MICE relatif terhitung sebagai segmen market baru di Hotel Malya Bandung di mana sebelumnya diposisikan sebagai leisure hotel atau weekenders and honeymooners hotel serta membidik pasar MICE mempunyai cara dan strategi yang sangat berbeda dan spesifik maka perlu dilakukannya suatu analisis faktor-faktor yang mempengaruhi keputusan pembelian jasa paket meeting pada Hotel Malya Bandung khususnya yang berkaitan dengan produk atribut dimana Hotel Malya Bandung telah melakukan investasi yang cukup besar untuk menyediakan fasilitas baru bagi pangsa pasar MICE.

\section{Perumusan Masalah Dan Tujuan}

Berdasarkan uraian latar belakang masalahan tersebut, maka dapat diidentifikasikan permasalahan dan tujuan penelitian sebagai berikut: 


\begin{tabular}{|l|l|}
\hline \multicolumn{1}{|c|}{ Perumusan Masalah } & \multicolumn{1}{|c|}{ Tujuan } \\
\hline Seberapa besar pengaruh atribut produk & Mengetahui besarnya pengaruh atribut \\
terhadap sikap pelanggan corporate meeting & produk terhadap sikap pelanggan corporate \\
di Hotel Malya Bandung- Bandung? & meeting di Hotel Malya Bandung- Bandung \\
\hline
\end{tabular}

\section{LANDASAN TEORI}

\section{Pemasaran Jasa}

Menurut Payne pemasaran jasa merupakan suatu proses mempersepsikan, memahami, menstimulasi dan memenuhi kebutuhan pasar sasaran yang dipilih secara khusus dengan menyalurkan sumber-sumber sebuah organisasi untuk memenuhi kebutuhan tersebut (Payne, 2013). Dengan demikian manajemen pemasaran jasa merupakan proses penyelerasan sumbersumber sebuah organisasi terhadap kebutuhan pasar. Fungsi pemasaran terdiri dari 3 komponen kunci, yaitu:

1. Bauran pemasaran (marketing mix), merupakan unsur-unsur internal penting yang membentuk program pemasaran sebuah organisasi

2. Kekuatan pasar, merupakan peluang dan ancaman eksternal di mana operasi pemasaran suatu organisasi berinteraksi.

3. Proses penyelerasan, yaitu proses strategik dan manajerial untuk memastikan bahwa kebijakan internal organisasi sudah layak untuk menghadapi kekuatan pasar.

(Payne, 2013).

Selain itu, Lovelock mengemukakan bahwa terdapat sembilan perbedaan dalam memasarkan produk jasa, yaitu:

1. pelanggan tidak menentukan kepemilikan dari jasa,

2. hasil produk jasa bersifat tidak nyata,

3. keterlibatan pelanggan dalam proses produksi sangat besar,

4. orang merupakan bagian dari produk jasa,

5. banyak variasi (jasa berubah-ubah) dalam menghasilkan input dan output,

6. banyak jasa yang sangat sulit untuk dinilai oleh pelanggan,

7. waktu merupakan faktor yang relatif lebih penting, 
8. sistem penyampaian jasa banyak melibatkan saluran distribusi fisik dan elektronik (Lovelock \& Jochen, 2011).

\section{Faktor Faktor Yang Berpengaruh Pada Industri Jasa Perhotelan}

\section{Atribut Produk}

Terdapat enam atribut yang dijadikan sebagai acuan bagi perusahaan ataupun para meeting planner dalam pemilihan hotel sebagai tempat pelaksanaan corporate meeting, yaitu:

a. Ruang Tidur Tamu (sleeping rooms)

b. Ruang Rapat (meeting rooms)

c. Makanan \& Minuman (food \& beverages)

d. Prosedur Pembayaran (billing procedures)

e. Check in dan check out

f. Pegawai (staff) (Kotler, Bowen, Makens, \& Seyhmus, 2017)

Keenam atribut di atas dapat diklasifikasikan menjadi: People, Physical evidence dan Process (Bojanic, 2008).

\section{Orang-Orang (People)}

Untuk mengukur kualitas pelayanan menurut James A. Fitzsimons \& Mona J (2006) adalah melalui karyawan (people), terdapat prinsip dimensi pelayanan sebagai tolak ukurnya, yaitu:

a. Reliability (Reliabilitas)

Kemampuan untuk memberikan secara tepat dan benar jenis pelayanan yang telah dijanjikan kepada tamu

b. Responsiveness (Responsif)

Kesadaran atau keinginan untuk cepat bertindak membantu tamu dan memberikan pelayanan yang tepat waktu.

c. Assurance (Jaminan kepastian)

Pengetahuan dan kesopan-santunan serta kepercayaan diri karyawan. Kompetensi untuk memberikan pelayanan, sopan dan memiliki sifat respek terhadap tamu.

d. Emphaty (Empati) 
Memberikan perhatian kepada para tamu secara khusus. Seperti: keinginan karyawan untuk melakukan pendekatan, memberikan perlindungan dan usaha untuk mengerti keinginan, kebutuhan dan perasaan tamu.

e. Tangibles (Nyata)

Sesuatu yang nampak atau yang nyata yang menunjang pelaksanaan pelayanan.

(Sulastiyono, 2011)

\section{Proses (Process)}

Menurut Christopher H. Lovelock (2011) dijelaskan bahwa manajemen pelayanan menitikberatkan pada proses dan didasarkan pada prinsip-prinsip manajemen pelayanan yang merubah pendekatan tradisional. Prinsip terbut adalah: (1) usaha yang logis dengan dorongan-dorongan tertentu hingga hotel dapat memperoleh keuntungan. (2) memberikan kewenangan kepada lapisan-lapisan struktur karyawan bawah tertentu untuk membuat keputusan yang berkaitan dengan pelayanan, (3) desain struktur organisasi harus disesuaikan dengan kebutuhan pelayanan, (4) pengendalian terhadap kepenyeliaan, (5) sistem penghargaan terhadap karyawan, dan (6) kegiatan yang dilakukan harus selalu dipantau dan diukur (Lovelock \& Jochen, 2011).

Output dari usaha perhotelan adalah tak terlihat (intangible) dan berlangsung dalam tenggang waktu yang singkat (ephemeral), maka dalam prosesnya hingga dapat dinikmati oleh tamu, unsur-unsur dan komponen dasar dalam pelayanan sulit diinventori. Oleh sebab itu pelayanan lebih berkaitan dengan proses, di mana produk yang dinikmati oleh tamu adalah berupa pengalaman. Oleh karenanya, pelayanan lebih berkaitan dengan proses, di mana produk yang dinikmati oleh tamu berupa pengalaman (Gasperz, 2012).

Proses-proses di mana jasa diciptakan dan disampaikan kepada pelanggan merupakan faktor utama di dalam bauran pemasaran jasa, karena para pelanggan akan seringkali mempersepsikan sistem penyampaian jasa sebagai bagian dari jasa itu. Proses adalah semua prosedur actual, mekanisme dan aliran aktivitas yang digunakan untuk menyampaikan jasa (Zeithaml V.A, 2013). Di mana prosedur aktual, mekanisme dan aliran aktivitas yang 
digunakan untuk menyampaikan jasa ini dapat berupa penyampaian informasi, penyesuaian kesepakatan, kemudahan koordinasi dan sistem pembayaran (Zeithaml V.A, 2013).

Proses meliputi prosedur, tugas-tugas, jadwal-jadwal, mekanisme, kegiatan dan rutinitas di mana suatu produk atau jasa disampaikan kepada pelanggan. Proses-proses dapat dipertimbangkan dengan dua cara: dalam hal kompleksitas dan divergensi. Kompleksitas berkaitan dengan karakteristik langkah-langkah dan urutan-urutan yang terdapat dalam proses tersebut, sementara divergensi mengacu pada ruang gerak atau variabilitas pelaksanaan langkah-langkah dan urutan-urutannya (Payne, 2013).

\section{Physical Evidence}

Physical evidence dapat membantu menciptakan environment (lingkungan) dan atmosfir yang mendukung terjadinya pembelian dan juga membantu image tentang jasa yang ditawarkan perusahaan dalam benak pelanggan. Hal ini sangat penting karena dapat mempengaruhi penilaian pelanggan terhadap jasa perusahaan dan merupakan penunjang dalam penyelenggaraan jasa. Dalam bisnis jasa, pemasar harus berusaha mengimbangi dimensi ketidakterwujudannya dengan menyediakan berkaitan dengan kondisi fisik untuk menguatkan positioning dan citra mengembangkan product surround (Tjiptono, 2012)

\section{Business-to-Business Marketing dan Perilaku Pembeli Organisasi}

Dalam business-to-business marketing, yang termasuk pembeli adalah organizational company, institusi dan pemerintahan. Persepsi utama pada $B$-to- $B$ adalah bahwa target penjualan bukan kepada organisasinya tetapi pada orang-orang yang bekerja di organisasi tersebut (Jayawardhena, 2010).

Tujuan daripada $B$-to-B Marketing adalah untuk menciptakan nilai-nilai bagi kedua perusahaan yang bertransaksi dengan menyelaraskan dan memadukan kapabilitas atau kemampuan pemasar dengan keinginan organisasi sebagai buyer (Jayawardhena, 2010).

\section{Perbedaan Pembeli Organisasi \& Pembeli Individu}

Istilah pelanggan sering dikategorikan menjadi 2 (Tanner, 2010), yaitu: 
a. Pelanggan secara individual (Personal Consumer) adalah individu yang membeli barang atau jasa untuk keperluan pribadinya. Dalam konteks ini barang atau jasa yang dibeli adalah untuk digunakan si pemakai (user).

b. Pelanggan secara organisasi (Organizational Consumer) meliputi: kelompok bisnis, pemerintah dan institusi. Pelanggan type ini membeli barang atau jasa dalam rangka menjalankan roda usahanya, baik yang berorientasi pada profit maupun non profit.

Selanjutnya, antara pasar pelanggan maupun pasar organisasi terdapat beberapa persamaan dan perbedaan, yaitu:

a. Perilaku organisasi dalam membeli lebih rasional

b. Perilaku organisasi dalam membeli melibatkan pembelian dalam jumlah besar

c. Proses pengambilan keputusan pembelian lebih kompleks

d. Evaluasi pembelian sangat spesifik

Sifat bauran pemasaran pada pasar organisasi:

a. Harga lebih fleksibel berdasarkan negosiasi

b. Promosi lebih ditekankan pada penjualan langsung (personal selling) dan trade show

c. Distribusi umumnya langsung dari produsen kepada organisasi yang bersangkutan.

Perusahaan yang menjual barang atau jasa kepada pasar organisasi harus memahami perilaku organisasi sebagai pembeli (organizational buyer behavior). Pemasar mengetahui bagaimana organisasi menanggapi berbagai stimulus bauran pemasaran (4P) dan stimulus lainnya seperti ekonomi, teknologi, politik, budaya, kompetisi. Seluruh stimulus yang masuk kedalam organisasi kemudian menjadi respon untuk melakukan pembelian. Di dalam organisasi, kegiatan membeli terdiri atas dua bagian penting, yaitu: buying center dan proses pengambilan keputusan pembelian (Tanner, 2010)

\section{Karakteristik Pasar Organisasional}

Pembeli organisasional biasanya menghadapi keputusan pembelian yang lebih kompleks dibanding pembeli pelanggan. Seringkali pembelian tersebut menyangkut jumlah uang yang sangat besar, pertimbangan-pertimbangan ekonomi dan teknis yang kompleks, serta interaksi yang rumit di antara banyak jenjang organisasi pembeli. Oleh karena pembelian 
tersebut lebih kompleks, pembeli organisasional lebih memerlukan waktu yang lama untuk mengambil keputusannya (Tanner, 2010).

Proses pembelian organisasional cenderung lebih formal. Pembelian organisasional yang besar memerlukan spesifikasi produk yang terperinci, syarat-syarat pembelian secara tertulis, survey yang ketat serta persetujuan formal. Dalam proses pembelian organisasional seringkali pembeli dan penjual mempunyai suatu saling ketergantungan yang lebih besar atas keduanya.

\section{Peranan Pada Pasar Organisational}

Unit pengambil keputusan dalam organisasi disebut buying center, yaitu individu-individu atau kelompok yang berperan serta dan bertanggung jawab dalam proses pengambilan keputusan pembelian sesuai dengan perannya. Buying center terdiri dari:

a. Users

Pengguna (users) adalah mereka yang akan menggunakan barang atau jasa. User-lah yang seringkali mempunyai inisiatif mengajukan proposal untuk membeli sesuatu.

\section{b. Influencers}

Pemberi pengaruh adalah mereka yang mempengaruhi pengambilan keputusan pembelian. Mereka membantu memberikan informasi dan alternative produk.

c. Deciders

Pengambil keputusan adalah mereka yang memiliki pengaruh secara formal maupun tidak formal untuk memilih atau menyetujui suplier. Dalam pembelian yang bersifat rutin buyers seringkali merupakan deciders atau approvers.

\section{d. Approvers}

Adalah mereka yang memberikan pengesahan persetujuan dilakukan berdasarkan usulan dari pengambil keputusan atau pembeli

e. Buyers

Pembeli adalah mereka yang memiliki kekuasaan formal/penuh untuk menyeleksi suplier dan mengatur tata cara pembelian serta berperan dalam negoisasi.

\section{f. Gatekeepers}

Gatekeeper memiliki kekuasaan untuk menyaring informasi atau mengendalikan arus informasi kepada orang lainnya.

(Tanner, 2010). 


\section{Sikap Pelanggan}

Untuk mengambil keputusan pembelian, dalam beberapa situasi, pelanggan melakukan pencarian informasi secara ekstensif dan kemudian memproses informasi itu sebagai bahan pertimbangan. Dalam beberapa situasi pula, pengambilan keputusan pembelian hanya memerlukan pencarian informasi sekadarnya saja dan memproses informasi secara sederhana pula. Pencarian dan perolehan informasi bisa dilakukan dengan berbagai cara, misalnya mencari iklan di berbagai majalah dan koran, mendengarkan dan melihat iklan di televisi, mendengarkan dari teman, tetangga atau orangtua dan lain-lain. Dengan perkataan lain, informasi bisa dari berbagai sumber yang ada.

Setelah pelanggan melakukan pencarian dan pemprosesan informasi, langkah berikutnya adalah menyikapi informasi yang diterimanya. Apakah pelanggan akan meyakini informasi yang diterimanya dan memilih merek tertentu untuk dibeli, hal itu berkaitan dengan sikap yang dikembangkan. Keyakinan-keyakinan dan pilihan pelanggan (preference) atas suatu merek adalah merupakan sikap pelanggan. Dalam banyak hal, sikap terhadap merek tertentu sering mempengaruhi apakah pelanggan akan membeli atau tidak. Sikap positif terhadap merek tertentu akan memungkinkan pelanggan melakukan pembelian terhadap merek itu, sebaliknya sikap negatif akan menghalangi pelanggan dalam melakukan pembelian (Tjiptono, 2012).

Sikap merupakan pernyataan evaluatif - baik yang menguntungkan atau tidak menguntungkan - mengenai obyek, orang atau peristiwa. Sikap mencerminkan bagaimana seseorang merasakan sesuatu (Peter \& Olson, 2008)

Gordon Aliport (dalam Sutisna) mendefinisikan sikap adalah mempelajari kecenderungan memberikan tanggapan pada suatu obyek atau kelompok obyek baik disenangi atau tidak disenangi secara konsisten (Sutisna, 2008). Jika definisi tersebut dianalogikan dengan sikap pelanggan terhadap merek produk berarti bahwa sikap terhadap merek yaitu mempelajari kecenderungan pelanggan untuk mengevaluasi merek baik disenangi atau tidak disenangi secara konsisten. Dengan demikian, pelanggan mengevaluasi merek tertentu secara keseluruhan dan yang paling jelek sampai yang paling baik.

\section{Komponen Sikap}

Sutisna membagi komponen sikap ke dalam 3 bagian, yaitu; 1) kepercayaan terhadap merek, 2) evaluasi merek dan 3) maksud untuk membeli (Sutisna, 2008). Kepercayaan 
merek, evaluasi merek dan maksud untuk membeli merupakan tiga komponen sikap yang digambarkan dalam gambar berikut ini.

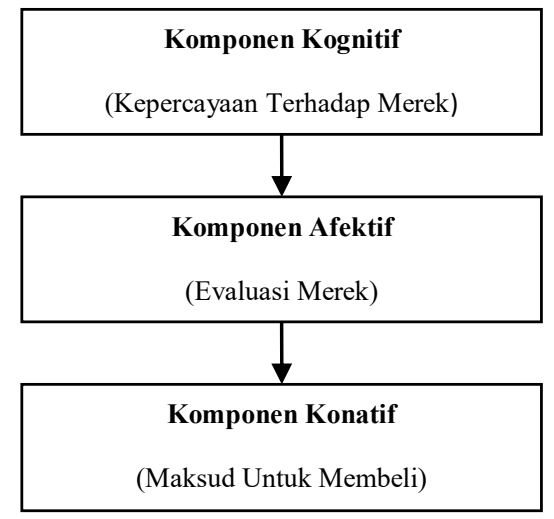

Gambar 1 Grafik tiga komponen sikap (Sutisna, 2008)

Kepercayaan merek adalah komponen kognitif dari sikap, evaluasi merek adalah komponen afektif atau perasaan dan maksud untuk membeli adalah komponen konatif atau tindakan. Hubungan antara tiga komponen itu mengilustrasikan hirarki pengaruh keterlibatan tinggi (high involvement), yaitu kepercayaan merek mempengaruhi evaluasi merek dan evaluasi merek mempengaruhi maksud untuk membeli.

Dari tiga komponen sikap, evaluasi merek adalah pusat dari telaah sikap karena evaluasi merek merupakan ringkasan dari kecenderungan pelanggan untuk menyenangi atau tidak menyenangi merek tertentu (Sutisna, 2008). Kepercayaan merek datang sebelum dan mempengaruhi evaluasi merek dan evaluasi merek terutama menentukan perilaku berkehendak. Dalam faktanya, evaluasi merek sesuai dengan definisi dari sikap terhadap merek, yaitu kecenderungan untuk mengevaluasi merek baik disenangi atau tidak disenangi (Sutisna, 2008)

Respon evaluatif dalam bentuk afektif berupa perasaan individu terhadap objek sikap. Evaluasi yang dilakukan individu terhadap berbagai objek yang diamati ini sesuai dengan pendapat yang dikemukakan oleh Aiken bahwa sikap adalah suatu predisposisi yang dipelajari untuk merespon secara konsisten, baik positif maupun negatif terhadap suatu objek. Dalam pandangan ini, respon yang diberikan individu diperoleh dari proses belajar terhadap berbagai atribut berkaitan dengan objek (Ramdhani, 2008). 


\section{Model Penelitian}

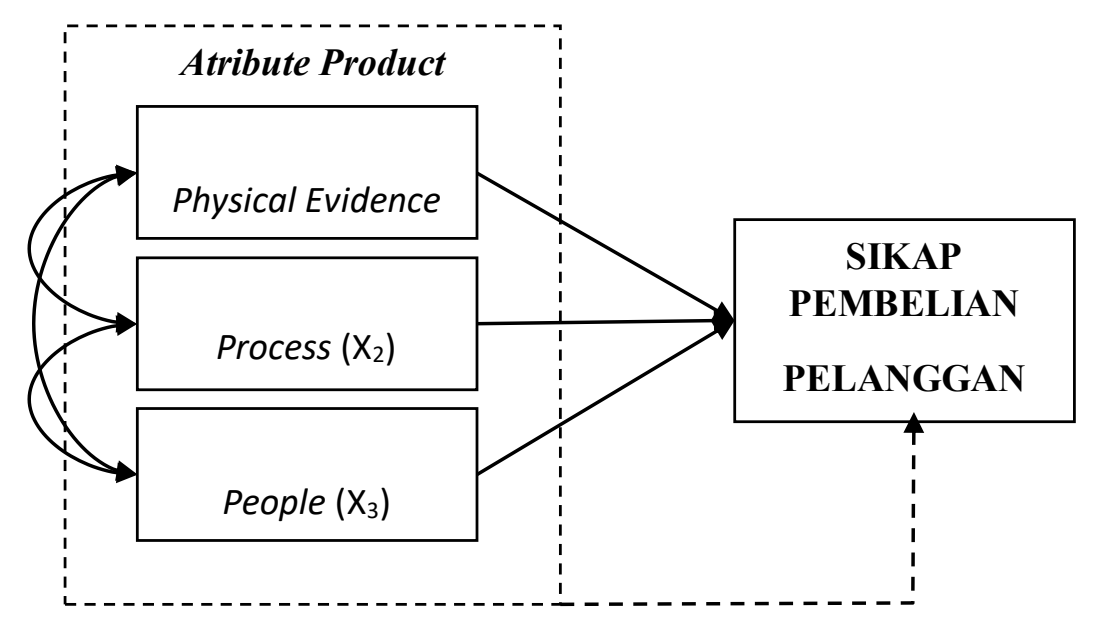

Gambar 2 Model penelitian

\section{Hipotesis}

$\mathrm{H}_{1}$ : Terdapat pengaruh yang signifikan antara atribut produk terhadap sikap pelanggan corporate meeting di Hotel Malya Bandung

$\mathrm{H}_{2}$ : Tidak terdapat pengaruh yang signifikan antara atribut produk terhadap sikap pelanggan corporate meeting

\section{METODOLOGI PENELITIAN}

Sesuai dengan identifikasi masalah dan tujuan penelitian yang dilakukan, metode penelitian yang digunakan dalam penelitian ini adalah sebagai berikut:

\begin{tabular}{|c|l|l|l|c|c|c|}
\hline Tujuan & Variabel & \multicolumn{1}{|c|}{ Sub Variabel } & Metodologi & $\begin{array}{c}\text { Teknis } \\
\text { Analitis } \\
\text { Data }\end{array}$ & $\begin{array}{c}\text { Output } \\
\begin{array}{c}\text { Menghitung } \\
\text { besarnya } \\
\text { pengaruh } \\
\text { atribut } \\
\text { produk } \\
\text { terhadap } \\
\text { sikap } \\
\text { pelanggan }\end{array}\end{array}$ & Atribut \\
\hline
\end{tabular}

Tabel 1 Metodologi Penelitian 


\section{Teknik Analisis Data}

Dalam mendefinisikan secara operasional variabel yang berhubungan dengan sikap, terkadang terlewatkan dimensi atau elemen penting atau memasukkan yang tidak relevan. Skala yang dibuat sering tidak sempurna, dan kesalahan mudah terjadi dalam pengukuran variabel yang berhubungan dengan sikap. Penggunaan instrumen yang lebih baik akan memastikan akurasi yang lebih tinggi dalam hasil, yang pada gilirannya, akan meningkatkan kualitas ilmiah penelitian. Karena itu, dengan cara tertentu, perlu dinilai ketepatan dari ukuran yang dibuat, yaitu perlu secara logis dipastikan bahwa instrumen yang digunakan dalam penelitian benar-benar mengukur variabel secara akurat (Sekaran, 2014).

\section{Uji Validitas}

Validitas adalah suatu ukuran yang menunjukkan tingkat keabsahan dan kevalidan suatu alat ukur atau instrumen penelitian. Validitas menunjukkan seberapa baik suatu instrumen yang dibuat mengukur konsep tertentu yang ingin diukur (Sekaran, 2014). Alat pengukur yang absah akan mempunyai validitas yang tinggi, begitu pula sebaliknya.

Untuk menguji validitas alat ukur atau instrumen penelitian, terlebih dahulu dicari nilai (harga) korelasi dengan menggunakan Rumus Koefisien Korelasi Product Moments Pearson sebagai berikut : $\quad r=\frac{n \sum X Y-\sum X \sum Y}{\sqrt{\left(n \sum X^{2}-\left(\sum X\right)^{2}\right) \times\left(n \sum Y^{2}-\left(\sum Y\right)^{2}\right)}}$

\section{Keterangan :}

$\mathrm{r} \quad=$ Koefisien korelasi

$\mathrm{n} \quad=$ Jumlah responden

$\mathrm{Y}=$ Jumlah skor total seluruh item Yi

$\mathrm{X} \quad=$ Jumlah skor tiap item Xi

Setelah nilai korelasi (r) didapat, kemudian dihitung nilai $t_{\text {hitung }}$ untuk menguji tingkat validitas alat ukur penelitian dengan rumus sebagai berikut:

$$
\mathrm{t}=\frac{\mathrm{r} \sqrt{\mathrm{n}-2}}{\sqrt{1-\mathrm{r}^{2}}}
$$

Keterangan :

$\mathrm{r}=$ Koefisien korelasi, $\quad \mathrm{n}=$ Jumlah responden 
Setelah nilai $t_{\text {hitung }}$ diperoleh, langkah selanjutnya adalah membandingkan nilai $t_{\text {hitung }}$ tersebut dengan nilai $t_{\text {tabel }}$ pada taraf signifikansi sebesar $\alpha=0,05$ dan derajat kebebasan $(\mathrm{dk})=\mathrm{n}-2$. Kaidah keputusannya adalah :

- $\quad J i k a t_{\text {hitung }}>t_{\text {tabel }}$, maka alat ukur atau instrumen penelitian yang digunakan adalah valid. (atau bertaraf signifikansi $<0.05$ )

- $\quad J i k a t_{\text {hitung }} \leq t_{\text {tabel }}$, maka alat ukur atau instrumen penelitian yang digunakan adalah tidak valid. (atau bertaraf signifikansi $\geq 0.05$ )

Uji validitas dilakukan terhadap alat ukur berupa kuesioner yang digunakan dalam penelitian ini terhadap variabel atribut produk maupun variabel sikap pembelian pelanggan Hotel Malya Bandung. Uji validitas terhadap item-item pernyataan ini dilakukan dengan menggunakan bantuan alat pengolahan data software SPSS Ver 12.

Berikut ditampilkan hasil pengujian validitas untuk variabel atribut produk meliputi; physycal evidence, process, people dan variabel sikap pembelian, meliputi pandangan responden mengenai Hotel Malya Bandung dengan alat bantu software Statistical Package for Social Science (SPSS) ver. 12.0, sebagai berikut: 
Tabel 2 Hasil Uji Validitas Mengenai Atribut Produk dan Sikap Pelanggan

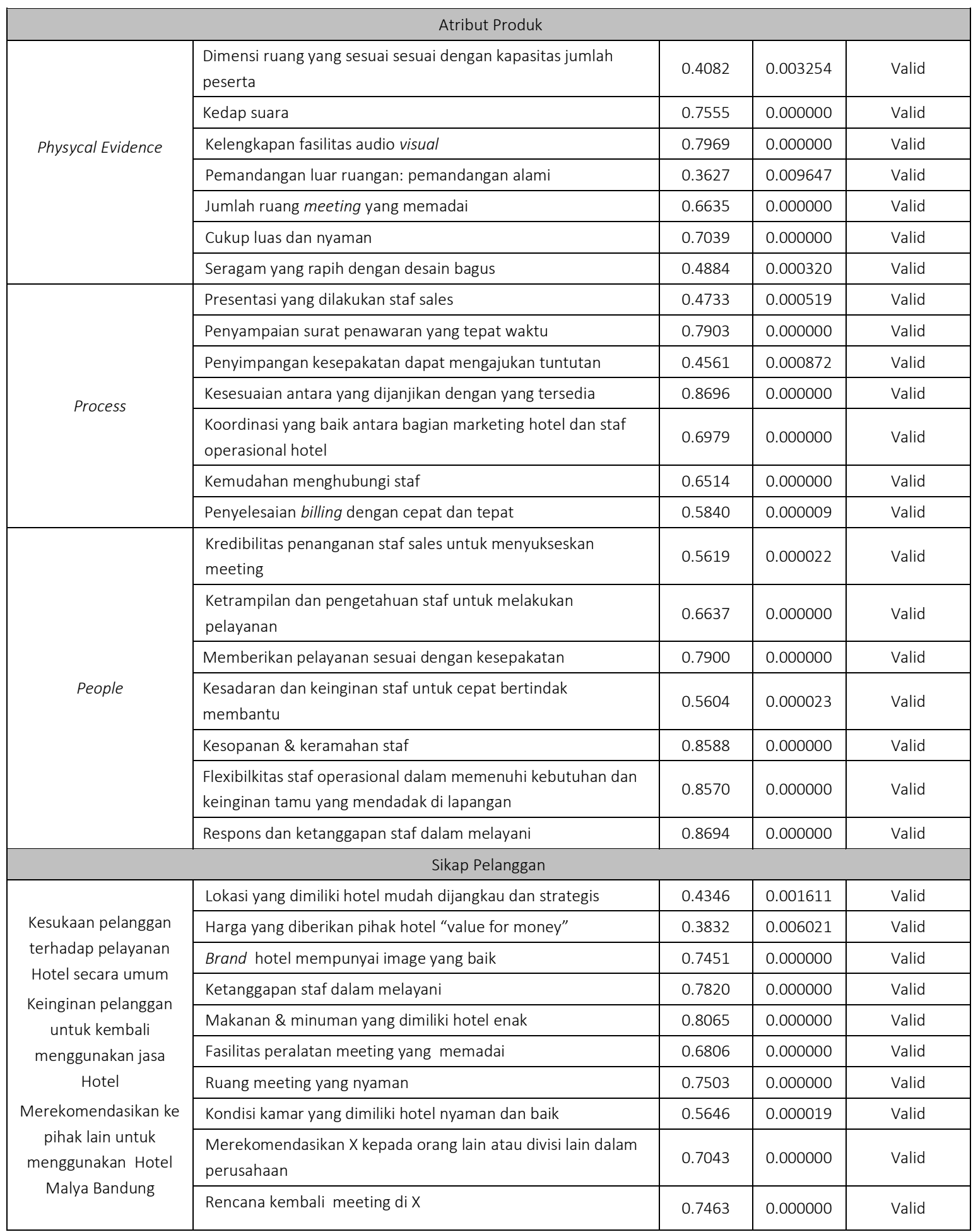

\section{Sumber: Pengolahan Data}

Tabel hasil uji validitas tersebut menunjukkan bahwa item-item pernyataan pada kuesioner atribut produk menunjukkan bahwa semua item pernyataannya dikatakan valid, begitu pula 
dengan item-item pernyataan pada kuesioner sikap pelanggan menunjukkan bahwa semua item pernyataannya dikatakan valid dengan taraf signifikansi $(\alpha)<0,05$; yang berarti bahwa setiap item pernyataan dapat dipergunakan untuk mengukur tingkat atribut produk berdasarkan dimensinya dan sikap pelanggan.

\section{Uji Reliabilitas}

Reliabilitas adalah indeks yang menunjukkan sejauh mana suatu pengukuran tanpa bias (bebas kesalahan) dan karena itu menjamin pengukuran yang konsisten lintas waktu dan lintas beragam item dalam instrumen (Sekaran, 2006: 40).

Untuk menguji reliabilitas atau keandalan alat ukur atau instrumen dalam penelitian ini digunakan koefisien Alpha Cronbach. Koefisien keandalan menunjukkan mutu seluruh proses pengumpulan data suatu penelitian. Koefisien Alpha Cronbach ditunjukkan dengan :

$$
\text { Alpha }(\alpha)=\frac{\mathrm{k} \cdot \overline{\mathrm{r}}}{1+(\mathrm{k}-1) \cdot \overline{\mathrm{r}}}
$$

\section{Keterangan:}

$\mathrm{k}=$ Jumlah variabel manifes yang membentuk variabel laten

$\bar{r} \quad=$ Rata-rata korelasi antar variabel manifes

Tujuan perhitungan koefisien keandalan adalah untuk mengetahui tingkat konsistensi jawaban responden. Besarnya koefisien ini berkisar dari nol hingga satu. Makin besar nilai koefisien, makin tinggi keandalan alat ukur dan tingkat konsistensi jawaban.

a. Jika rs $<0,20$ maka pengaruh antara kedua variabel sangat lemah atau tidak ada hubungan sama sekali

b. Jika rs diantara $0,20-0,40$ maka ditafsirkan bahwa terdapat pengaruh yang rendah tetapi pasti.

c. Jika rs diantara 0,40-0,70 maka ditafsirkan bahwa terdapat pengaruh yang cukup berarti. 
d. Jika rs diantara $0,70-0,90$ maka ditafsirkan bahwa terdapat pengaruh yang tinggi

e. Jika rs $>0,90$ maka ditafsirkan bahwa terdapat pengaruh yang sangat tinggi.

Uji reliabilitas dilakukan terhadap alat ukur berupa kuesioner yang digunakan dalam penelitian ini terhadap variabel atribut produk maupun terhadap variabel sikap pembelian pelanggan Hotel Malya Bandung. Uji reliabilitas terhadap variabel penelitian ini dilakukan dengan menggunakan bantuan alat pengolahan data software SPSS Ver 12.

Berikut ini ditampilkan tabel hasil uji reliabilitas variabel-variabel penelitian yang akan diuji, yaitu; variabel atribut produk yang merupakan kenyataan yang dirasakan responden, meliputi; physycal evidence $\left(\mathrm{X}_{1}\right)$, process $\left(\mathrm{X}_{2}\right)$, people $\left(\mathrm{X}_{3}\right)$ dan variabel sikap pelanggan (Y), dilakukan dengan menggunakan bantuan alat pengolahan data software SPSS Ver 12, sebagai berikut:

Tabel 3 Realibilitas Variabel Penelitian

\begin{tabular}{|c|l|c|c|}
\hline No. & \multicolumn{1}{|c|}{ Variabel } & $\begin{array}{c}\text { Cronbach's } \\
\text { Alpha }\end{array}$ & Ket. \\
\hline 1 & Physical Evidence $\left(\mathrm{X}_{1}\right)$ & 0.6684 & Reliabel \\
\hline 2 & Process $\left(\mathrm{X}_{2}\right)$ & 0.7451 & Reliabel \\
\hline 3 & People $\left(\mathrm{X}_{3}\right)$ & 0.8673 & Reliabel \\
\hline 4 & Sikap Pelanggan $(\mathrm{Y})$ & 0.8188 & Reliabel \\
\hline
\end{tabular}

Sumber: Pengolahan Data

Tabel hasil uji reliabilitas tersebut menunjukkan bahwa untuk setiap variabel penelitian yang akan dipergunakan untuk pengujian telah memenuhi kategori reliabel, dengan kriteria reliabel Alpha Cronbach $>0.5$. Hal ini memberikan informasi bahwa jawaban responden terhadap kuesioner yang dipergunakan memperlihatkan kekonsistenan, sehingga hasil perolehan skor jawaban kuesioner dapat dipergunakan dan dianalisis lebih lanjut.

\section{Analisis Data}

Penelitian ini secara kuantitatif dianalisis pengaruh atribut produk yang dirasakan pelanggan terhadap sikap pembelian pelanggan Hotel Malya Bandung dengan menggunakan analisis jalur. Metode analisis data ini dilakukan dengan cara menganalisis 
data yang diperoleh melalui kuesioner. Metode ini bertujuan untuk menggambarkan hasil pengolahan data yang tertera dalam lembaran koding yang merupakan jawaban dari responden. Data tersebut disusun dan diklasifikasikan dalam bentuk tabel distribusi frekuensi. Hal itu bertujuan untuk memudahkan proses analisis dan interpretasi.

Pengukuran tingkat atribut produk digunakan dengan skala yang tetap sehingga perusahaan dapat lebih mengerti atribut produk yang merupakan tingkat kepentingan serta tingkat kinerja Hotel Malya Bandung berdasarkan sikap pelanggan. Instrumen tersebut dirancang berdasarkan 3 (tiga) subvariabel, yaitu; physical evidence, process, dan people serta sikap pembelian pelanggan diukur berdasarkan 1 (satu) variabel.

\section{Analisis Jalur}

Setelah dilakukan pengujian validitas dan reliabilitas suatu alat ukur atau instrumen berupa kuesioner, dan data dinyatakan valid serta reliabel, maka selanjutnya dapat dilakukan analisa data.

Pada tahap analisis, data diolah dan diproses menjadi kelompok-kelompok, diklasifikasikan, dikategorikan dan dimanfaatkan untuk memperoleh kebenaran sebagai jawaban dari masalah dalam hipotesis yang diajukan dalam penelitian. Penelitian yang dilakukan ini bermaksud untuk mengungkapkan adanya pengaruh antara variabel penyebab atau independent variable dengan variabel akibat atau dependent variable. Dalam statistika, metode analisis yang sesuai dengan permasalahan tersebut adalah analisis jalur, di mana satu variabel akibat dipengaruhi oleh beberapa variabel penyebabnya, dan antara variabel penyebab terdapat hubungan

Pada bagian sebelumnya telah ditentukan bahwa variabel akibat pada penelitian ini adalah sikap pembelian pelanggan (Y), sedangkan variabel penyebabnya adalah berdasarkan atribut produk yang diambil berdasarkan atribut produk meliputi; physical evidence $\left(\mathrm{X}_{1}\right)$, process $\left(\mathrm{X}_{2}\right)$ dan people $\left(\mathrm{X}_{3}\right)$. Untuk itu, struktur hubungan sebab akibat yang dapat digambarkan sebagai berikut : 


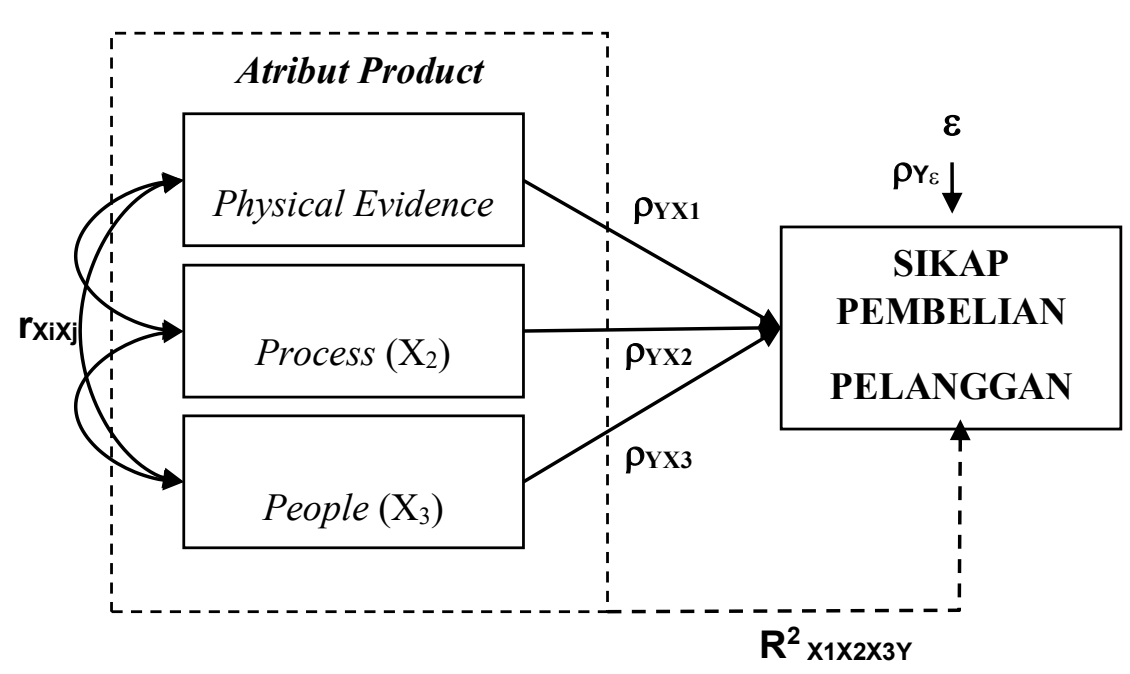

Gambar 3 Model pengaruh atribut produk terhadap sikap pelanggan

Keterangan :

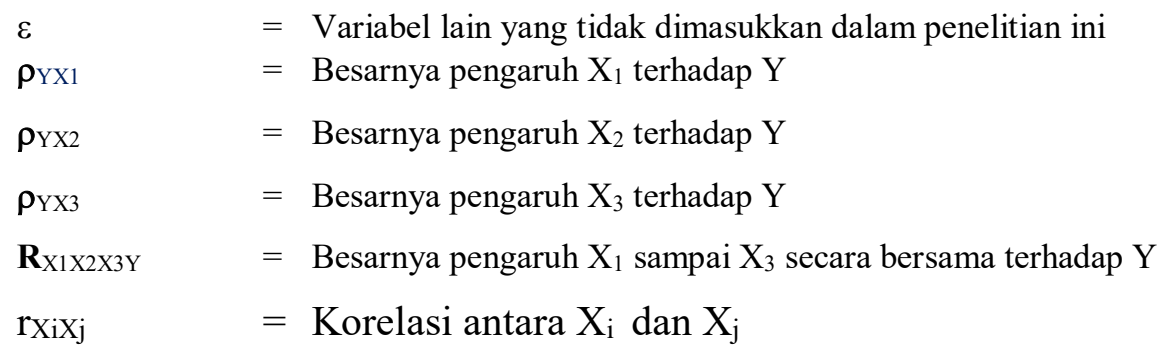

Untuk menghitung koefisien jalur pada stuktur hubungan yang digunakan dalam pengujian hipotesis dilakukan berdasarkan matriks invers korelasi, dengan langkah kerja sebagai berikut :

a. Menghitung koefisien korelasi sederhana antar variabel, melalui rumus sebagai berikut :

$$
r_{X_{i} X_{j}}=\frac{n \sum_{h=1}^{n} X_{i h} X_{j h}-\sum_{h=1}^{n} X_{i h} \sum_{h=1}^{n} X_{j h}}{\sqrt{\left[n \sum_{h=1}^{n} X_{i h}^{2}-\left(\sum_{h=1}^{n} X_{i h}\right)^{2}\right]\left[n \sum_{h=1}^{n} X_{j h}^{2}-\left(\sum_{h=1}^{n} X_{j h}\right)^{2}\right]}} ; i \neq j=1,2, \ldots, k
$$

b. Membentuk matriks korelasi antara variabel. Nilai koefisien korelasi antar variabel dibentuk ke dalam matriks korelasi sebagai berikut :

c. Menghitung matriks invers korelasi antar variabel

\begin{tabular}{|l|l|l|l|}
\hline $\mathrm{X}_{1}$ & $\mathrm{X}_{2}$ & $\mathrm{X}_{3}$ & \\
\hline $\mathrm{r}_{\mathrm{x}_{1} \mathrm{x}_{1}}$ & $\mathrm{r}_{\mathrm{X}_{1} \mathrm{x}_{2}}$ & $\mathrm{r}_{\mathrm{x}_{1} \mathrm{x}_{3}}$ & $\mathrm{X}_{1}$ \\
\hline & $\mathrm{r}_{\mathrm{X}_{2} \mathrm{x}_{2}}$ & $\mathrm{r}_{\mathrm{x}_{2} \mathrm{x}_{3}}$ & $\mathrm{X}_{2}$ \\
\hline & & $\mathrm{r}_{\mathrm{x}_{3} \mathrm{x}_{3}}$ & $\mathrm{X}_{3}$ \\
\hline
\end{tabular}




\begin{tabular}{|l|l|l|l|}
\hline $\mathrm{X}_{1}$ & $\mathrm{X}_{2}$ & $\mathrm{X}_{3}$ & \\
\hline $\mathrm{CR}_{\mathrm{X}_{1} \mathrm{X}_{1}}$ & $\mathrm{CR}_{\mathrm{X}_{1} \mathrm{X}_{2}}$ & $\mathrm{CR}_{\mathrm{X}_{1} \mathrm{X}_{3}}$ & $\mathrm{X}_{1}$ \\
\hline & $\mathrm{CR}_{\mathrm{X}_{2} \mathrm{X}_{2}}$ & $\mathrm{CR}_{\mathrm{X}_{2} \mathrm{X}_{3}}$ & $\mathrm{X}_{2}$ \\
\hline & & $\mathrm{CR}_{\mathrm{X}_{3} \mathrm{X}_{3}}$ & $\mathrm{X}_{3}$ \\
\hline
\end{tabular}

d. Menghitung koefisien jalur dengan rumus:

$$
\rho_{Y X_{i}}=\frac{-\mathrm{CR}_{Y X_{i}}}{\mathrm{CR}_{Y Y}} ; \mathrm{i}=1,2, \ldots, k
$$

Keterangan :

$\rho_{\mathrm{YX}_{\mathrm{i}}}=\quad$ Koefisien jalur dari variabel $\mathrm{X}_{\mathrm{i}}$ terhadap variabel $\mathrm{Y}$

$\mathrm{CR}_{\mathrm{YX}_{\mathrm{i}}}=\quad$ Sel pada baris ke-Y dan kolom ke- $\mathrm{X}_{\mathrm{i}}$ dari matriks invers korelasi

$\mathrm{CR}_{\mathrm{YY}}=\quad$ Sel pada baris ke-Y dan kolom ke-Y dari matriks invers korelasi

e. Menghitung koefisien determinasi tiap variabel $\left(\mathrm{R}_{\mathrm{YX}}\right)$

$$
\mathrm{R}_{\mathrm{YXi}}=\rho_{\mathrm{YXi}} \cdot \mathrm{r}_{\mathrm{YXi}}
$$

f. Menghitung koefisien determinasi multipel dengan rumus:

$$
R_{Y X_{1 . . .} X_{k}}^{2}=\sum_{i=1}^{k} \rho_{Y X_{i}} r_{Y X_{i}}
$$

g. Menghitung tingkat signifikan pengaruh tiap sub variabel atribut produk dengan rumus:

$$
t_{i}=\frac{\rho_{Y X_{i}}}{\sqrt{\frac{\left(1-R_{Y X_{1} \ldots X_{k}}^{2}\right) \mathrm{CR}_{i i}}{n-k-1}}} ; \mathrm{i}=1,2, \ldots, \mathrm{k}
$$

h. Menghitung koefisien jalur variabel lain dengan rumus :

$$
\rho_{Y \varepsilon}=\sqrt{1-R_{Y\left(X_{1} X_{2} \ldots X_{k}\right)}^{2}}
$$


Besarnya pengaruh dari suatu variabel penyebab terhadap variabel akibat disebut dengan koefisien jalur dan diberi simbol $\rho_{\mathrm{X}_{\mathrm{i}} \mathrm{X}_{\mathrm{j}}}$. Besarnya pengaruh dari $\mathrm{X}_{1}$ terhadap $\mathrm{Y}$ dinyatakan oleh besarnya nilai numerik koefisien jalur yaitu $\rho_{\mathrm{YX} 1}$, pengaruh dari $\mathrm{X}_{2}$ terhadap $\mathrm{Y}$ dinyatakan dengan $\rho_{\mathrm{YX} 2}$, dan seterusnya. Pengaruh variabelvariabel lain di luar variabel $X_{1}$ sampai $X_{3}$ terhadap $Y$ adalah $\rho_{Y \varepsilon}$.

Setelah nilai koefisien jalur diketahui, selanjutnya dilakukan penjabaran analisis jalur dengan kriteria; 1) pengaruh langsung variabel penyebab $\mathrm{X}_{\mathrm{i}}$ terhadap variabel akibat $\left.\mathrm{Y}\left(\mathrm{Y} \leftarrow \mathrm{X}_{\mathrm{i}} \rightarrow \mathrm{Y}\right)=\rho_{\mathrm{YX}_{\mathrm{i}}} \mathrm{x} \rho_{\mathrm{Yx}_{\mathrm{i}}}, 2\right)$ pengaruh tak langsung variabel penyebab $\mathrm{X}_{\mathrm{i}}$ terhadap $\mathrm{Y}$ melalui $\mathrm{X}_{\mathrm{j}}(\mathrm{Y} \leftarrow \mathrm{Xi} \Omega \mathrm{Xj} \rightarrow \mathrm{Y})=\rho_{\mathrm{Yx}_{\mathrm{i}}} \times r_{\mathrm{X}_{\mathrm{i}} \mathrm{X}_{\mathrm{j}}} \times \rho_{\mathrm{Yx}_{\mathrm{j}}}$ 3) jumlah pengaruh langsung dan tak langsung $X_{i}$ terhadap $Y$ melalui $X_{j}=\rho_{\mathrm{Yx}_{\mathrm{i}}} \times \rho_{\mathrm{YX}_{\mathrm{i}}}+\sum \rho_{\mathrm{Yx}_{\mathrm{i}}} \times \mathrm{r}_{\mathrm{X}_{\mathrm{i}} \mathrm{X}_{\mathrm{j}}} \mathrm{X} \rho_{\mathrm{Yx}_{\mathrm{j}}}$, 4) pengaruh variabel lain di luar model (galat) : $\rho_{\mathrm{Y} \varepsilon}=\sqrt{ }\left(1-R_{Y X_{1 \ldots} X_{k}}^{2}\right)$

\section{Pengujian Hipotesis}

Berdasarkan kerangka pikir yang telah dikemukakan telah ditentukan hipotesis penelitian adalah sebagai berikut :

"Terdapat Pengaruh Atribut Produk terhadap Sikap Pembelian Pelanggan Corporate Meeting di Hotel Malya Bandung”.

Hipotesis yang diajukan dalam penelitian ini diuji dengan menggunakan analisis jalur (Path Analysis). Adapun pengujian hipotesis dilakukan dengan analisis jalur yang sesuai dengan paradigma yang mencerminkan hipotesis tersebut. Karena pada dasarnya hubungan struktural antar variabel menggambarkan suatu regresi ganda (multiple regression), maka persamaan linier yang mendasari perhitungan koefisien jalur, adalah sebagai berikut :

$$
\mathbf{Y}=\rho_{\mathrm{YX} 1} \mathbf{X}_{1}+\rho_{\mathrm{YX} 2} \mathbf{X}_{2}+\rho_{\mathrm{YX} 3} \mathbf{X}_{3}+\varepsilon
$$

a. Pengujian Secara Keseluruhan

Hipotesis pada pengujian secara keseluruhan ini adalah :

Ho : $\rho_{\mathrm{YX}_{1}}=\rho_{\mathrm{YX}_{2}}=\rho_{\mathrm{YX}_{3}}=0$, yaitu tidak terdapat pengaruh variabel penyebab terhadap variabel akibat.

$\mathrm{H}_{1}$ : Sekurang-kurangnya ada sebuah $\mathrm{P}_{Y X_{i}} \neq 0,(i=1,2,3)$, yaitu terdapat satu atau lebih pengaruh variabel penyebab terhadap variabel akibat 
Rumus pengujian pada koefisien jalur secara keseluruhan :

$$
F=\frac{(n-k-1) \sum_{i=1}^{k} p_{Y X_{i}} r_{Y X_{i}}}{k\left(1-\sum p_{Y X_{i}} r_{Y X_{i}}\right)}
$$

Statistik uji di atas mengikuti distribusi F-Snedecor dengan derajat bebas penyebut $\left(\mathrm{v}_{1}=\mathrm{k}\right)$ dan derajat bebas pembilang $\left(\mathrm{v}_{2}=\mathrm{n}-\mathrm{k}-1\right)$, di mana $\mathrm{n}$ adalah jumlah sampel dan $\mathrm{k}$ adalah jumlah variabel penelitian dengan kriteria pengujian:

Tolak Ho jika $p$-value $\leq \alpha$, lainnya terima jika $p$-value $>\alpha$.

b. Pengujian Secara Individual

Apabila pada pengujian secara keseluruhan Ho ditolak berarti sekurang-kurangnya ada sebuah $\rho_{\mathrm{YX}_{\mathrm{i}}} \neq 0$. Untuk mengetahui $\rho_{\mathrm{YX}_{\mathrm{i}}}$ mana yang sama dengan nol, atau untuk menguji hipotesis konseptual yang diajukan, maka dilakukan pengujian secara individual.

Langkah kerja pada pengujian koefisien jalur ini adalah menentukan hipotesis statistik yang akan diuji sebagai berikut:

Ho : $\rho_{\mathrm{YX}_{\mathrm{i}}}=0$, yaitu tidak terdapat pengaruh antara variabel penyebab terhadap variabel akibat, melawan

$\mathrm{H}_{1}: \boldsymbol{\rho}_{\mathrm{YX}_{\mathrm{i}}} \neq 0, \quad$ yaitu terdapat pengaruh antara variabel penyebab terhadap variabel akibat.

Statistik uji yang digunakan adalah statistik $\mathrm{t}_{\mathrm{i}}$ berdasarkan nilai-nilai matriks invers korelasi yaitu :

$$
t_{i}=\frac{\rho_{Y X_{i}}}{\sqrt{\frac{\left(1-R_{Y X_{1} \ldots X_{k}}^{2}\right) \mathrm{CR}_{i i}}{n-k-1}}} ; \mathrm{i}=1,2, \ldots, \mathrm{k}
$$

Statistik uji di atas mengikuti distribusi t dengan derajat bebas $n-k-1$, dimana: 


$$
\begin{gathered}
R_{Y X_{1 . .} X_{k}}^{2}=\sum_{i=1}^{k} \rho_{Y X_{i}} r_{Y X_{i}} \\
\rho_{Y X_{i}}=\frac{-\mathrm{CR}_{Y X_{i}}}{\mathrm{CR}_{Y Y}} ; \mathrm{i}=1,2, \ldots, k
\end{gathered}
$$

Keterangan :

$\rho_{\mathrm{YXi}}=$ koefisien jalur atau besarnya pengaruh dari variabel penyebab $\mathrm{X}_{\mathrm{i}}$ terhadap variabel akibat $\mathrm{Y}$

$$
r_{X_{i} X_{j}}=\frac{n \sum_{h=1}^{n} X_{i h} X_{j h}-\sum_{h=1}^{n} X_{i h} \sum_{h=1}^{n} X_{j h}}{\sqrt{\left[n \sum_{h=1}^{n} X_{i h}^{2}-\left(\sum_{h=1}^{n} X_{i h}\right)^{2}\right]\left[n \sum_{h=1}^{n} X_{j h}^{2}-\left(\sum_{h=1}^{n} X_{j h}\right)^{2}\right]}} ; i \neq j=1,2, \ldots, k
$$

Keterangan :

$\mathrm{R}_{\mathrm{YX}_{1} \ldots \mathrm{X}_{\mathrm{k}}}^{2}=$ koefisien determinasi yang menyatakan determinasi total dari semua variabel penyebab terhadap variabel akibat.

$\mathrm{CR}_{\mathrm{ii}}=$ merupakan unsur pada baris ke-i dan kolom ke-i dari matriks invers korelasi

Jika dari hasil pengujian secara individu menunjukkan bahwa terdapat variabel yang tidak berpengaruh, maka diperlukan koefisien jalur baru. Untuk mendapatkan koefisien jalur baru, dilakukan perhitungan ulang tanpa melibatkan variabel yang tidak berpengaruh signifikan.

\section{HASIL DAN PEMBAHASAN}

\section{Proses Pengumpulan Kuesioner}

Hasil pengumpulan data dengan mempergunakan kuesioner yang disebarkan kepada 68 perusahaan sebagai pengguna jasa corporate meeting di Hotel Malya Bandung pada periode Juli sampai Desember 2017. 
Dari 68 kuesioner yang disebar, yang kembali sebanyak 59 kuesioner. Dari jumlah kuesioner yang kembali terdapat 50 kuestioner yang sah yang dipergunakan menjadi data primer untuk pengolahan data. Kuesioner dianggap sah jika pernyataan pada kuesioner dijawab seluruhnya dan pada setiap pernyataan hanya ada satu jawaban. Adapun penelitian ini dilakukan selama akhir Desember 2017 sampai Maret 2018.

\section{Analisis Data}

Hasil pengumpulan data dengan mempergunakan kuesioner berskala Likert menghasilkan data dengan skala pengukuran ordinal. Agar dapat diolah dengan analisis jalur yang mensyaratkan data minimal berskala interval, maka data yang diperoleh dalam bentuk skala pengukuran ordinal, terlebih dahulu ditransformasikan ke dalam bentuk skala pengukuran interval dengan menggunakan Metoda Successive Interval.

Pada analisi jalur ini dapat dilihat hubungan antar variabel dengan istilah sebab akibat antara variabel attitude product, yang meliputi; physical evidence $\left(\mathrm{X}_{1}\right)$, process $\left(\mathrm{X}_{2}\right)$ dan people $\left(\mathrm{X}_{3}\right)$ sebagai variabel penyebab terhadap variabel sikap pelanggan $(\mathrm{Y})$ sebagai variabel akibat, di mana antar variabel penyebab terdapat hubungan timbal balik (saling berkorelasi).

Dengan mempergunakan data hasil transformasi mempergunakan metoda successive interval, dan pengolahan data analisis jalur dilakukan dengan alat bantu software SPSS Ver 12.0 (hasil output pada Lampiran 10) diperoleh hasil koefisien jalur sebagai berikut :

$$
\begin{aligned}
& \rho_{Y X_{1}}=-0.100 \\
& \rho_{Y X_{2}}=-0.025 \\
& \rho_{Y X_{3}}=0.633
\end{aligned}
$$

Koefisien korelasi antar variabel akibat, sebagai berikut :

Tabel 4 Hasil Koefisien Korelasi Antar Variabel Akibat

\begin{tabular}{|l|r|r|r|}
\hline & \multicolumn{1}{|c|}{$\mathbf{X}_{\mathbf{1}}$} & \multicolumn{1}{|c|}{$\mathbf{X}_{\mathbf{2}}$} & \multicolumn{1}{|c|}{$\mathbf{X}_{\mathbf{3}}$} \\
\hline $\mathbf{X}_{\mathbf{1}}$ & 1 & 0.053 & 0.184 \\
\hline $\mathbf{X}_{\mathbf{2}}$ & 0.053 & 1 & 0.650 \\
\hline $\mathbf{X}_{\mathbf{3}}$ & 0.184 & 0.805 & 1 \\
\hline \multicolumn{3}{|c|}{ Sumber: Hasil Pengolahan Data } \\
\hline
\end{tabular}


Koefisien determinasi diperoleh nilai $\mathrm{R}^{2} \mathrm{YX} 1 \mathrm{X} 2 \ldots \mathrm{X} 8=0.363$. Sedangkan pengaruh variabel lain di luar variabel yang dipergunakan diperoleh dengan mempergunakan rumus, sebagai berikut:

$$
\begin{aligned}
& \rho_{\mathrm{Y} \varepsilon}=\sqrt{1-\mathrm{R}^{2} \mathrm{YX}_{1} \mathrm{X}_{2} \mathrm{X}_{3}} \\
& \rho_{\mathrm{Y} \varepsilon}=\sqrt{1-0.363}=0.798
\end{aligned}
$$

Persamaan fungsi struktural untuk diagram jalur diperoleh:

$$
\mathrm{Y}=-0.100 \mathrm{X}_{1}-0.025 \mathrm{X}_{2}+0.633 \mathrm{X}_{3}+\varepsilon
$$

Berdasarkan persamaan analisis jalur tersebut maka penggambaran struktur hubungan kausal antara variabel penyebab dan variabel akibat dapat dilihat di bawah ini,

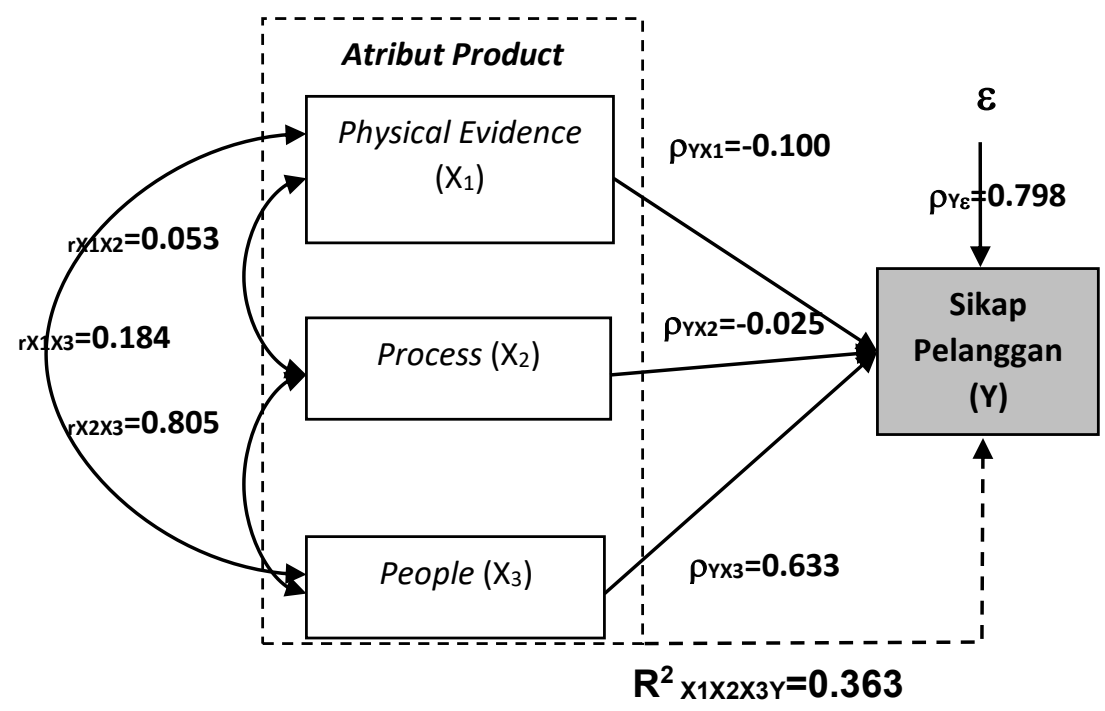

Gambar 4 Nilai koefisien jalur hubungan struktural

H0 : Tidak terdapat pengaruh atribut produk terhadap sikap pelanggan baik pengaruh langsung maupun pengaruh tak langsung.

$\mathrm{H}_{1}$ : Terdapat pengaruh atribut produk terhadap sikap pelanggan baik pengaruh langsung maupun pengaruh tak langsung.

Hipotesis tersebut ditujukan untuk mengetahui keberartian dari koefisien jalur, sehingga pengujian hipotesis statistiknya dapat digunakan dalam bentuk sebagai berikut :

$$
\mathrm{H}_{\mathrm{o}}: \rho \mathrm{Yx}_{\mathrm{i}} \leq 0 \text { melawan } \mathrm{H}_{1}: \rho \mathrm{YX}_{\mathrm{i}}>0 \text {; dimana } \mathrm{i}=1,2,3
$$


Sebelum menguji hipotesis tersebut, terlebih dahulu dilakukan pengujian secara keseluruhan dengan perumusan sebagai berikut :

$\mathrm{H}_{\mathrm{o}}: \rho \mathrm{Yx}_{1}=\rho \mathrm{Yx}_{2}=\rho \mathrm{Yx}_{3}=0$

H1 : sekurang-kurangnya ada sebuah $\rho \mathrm{Yx}_{1} \neq 0$; dimana $\mathrm{i}=1,2,3$

Berdasarkan hasil pengolahan data analisis jalur diperoleh nilai signifikan $\mathrm{F}$ sebesar 0.000 (lebih kecil dari $\alpha=0,05$ ) yang menunjukkan hasil pengujian bahwa Ho ditolak sehingga $\mathrm{H}_{1}$ diterima yang berarti bahwa sekurang-kurang terdapat satu variabel penyebab berpengaruh terhadap varibel akibatnya, sehingga dilanjutkan dengan pengujian secara individu.

Untuk menguji pengujian secara individual untuk mengeluarkan variabel penyebab yang tidak berpengaruh signifikan terhadap variabel akibatnya dipergunakan metode backward. Berdasarkan hasil pengolahan data analisis jalur diperoleh nilai signifikan t untuk variabel physical evidence $\left(\mathrm{X}_{1}\right)$ sebesar $-0,824$, process $\left(\mathrm{X}_{2}\right)$ sebesar $-0,123$, dan People $\left(\mathrm{X}_{3}\right)$ sebesar 3.102. Dengan mempergunakan tingkat signifikansi tidak lebih dari $\alpha=0,05$; diperoleh variabel process $\left(\mathrm{X}_{2}\right)$ yang bersignifikansi $\alpha=0.903$ tidak berpengaruh terhadap sikap pelanggan.

Adanya variabel penyebab process $\left(\mathrm{X}_{2}\right)$ yang tidak berpengaruh terhadap sikap pembelian, maka besarnya koefisien jalur akan berubah, sehingga perlu dilakukan pengolahan data untuk mendapatkan koefisien jalur baru.

Untuk mencari koefisien jalur yang baru maka perlu dilakukan pengujian kedua tanpa mengikutsertakan variabel process $\left(\mathrm{X}_{2}\right)$. Hasil pengolahan data analisis jalur baru diperoleh nilai koefisien jalur sebesar :

$$
\begin{aligned}
& \rho_{Y X_{1}}=-0.097 \\
& \rho_{Y X_{3}}=0.613
\end{aligned}
$$

Koefisien determinasi diperoleh nilai $\mathrm{R}^{2} \mathrm{YX}_{\mathrm{XX} 3}=0.363$. Sedangkan pengaruh variabel lain di luar variabel yang dipergunakan diperoleh dengan mempergunakan rumus sebagai berikut :

$$
\begin{aligned}
& \rho \mathrm{Y} \varepsilon=\sqrt{1-\mathrm{R}^{2} \mathrm{YX1X3}} \\
& \rho_{Y \varepsilon}=\sqrt{1-0.363}=0.798
\end{aligned}
$$


Persamaan fungsi struktural untuk diagram jalur yang baru diperoleh:

$$
\mathrm{Y}=-0.097 \mathrm{X} 1+0.613 \mathrm{X} 3+\varepsilon
$$

Berdasarkan hasil pengolahan data analisis jalur baru diperoleh nilai signifikan $\mathrm{t}$ untuk variabel physical evidence $\left(\mathrm{X}_{1}\right)$ sebesar $-0,823$ dan people $\left(\mathrm{X}_{3}\right)$ sebesar 5.176. Dengan mempergunakan tingkat signifikansi tidak lebih dari $\alpha=0,05$; diperoleh variabel physical evidence $\left(\mathrm{X}_{1}\right)$ yang bersignifikansi $\alpha=0.415$ tidak berpengaruh terhadap sikap pelanggan.

Adanya variabel penyebab physical evidence $\left(\mathrm{X}_{1}\right)$ yang tidak berpengaruh terhadap sikap pelanggan, maka besarnya koefisien jalur akan berubah, sehingga perlu dilakukan pengolahan data untuk mendapatkan koefisien jalur baru.

Untuk mencari koefisien jalur yang baru maka perlu dilakukan pengujian ketiga tanpa mengikutsertakan variabel physical evidence $\left(\mathrm{X}_{1}\right)$. Hasil pengolahan data analisis jalur baru diperoleh nilai koefisien jalur sebesar : $\rho_{Y X_{3}}=0.595$ dan koefisien determinasi diperoleh nilai $\mathrm{R}^{2} \mathrm{YX} 3=0.354$. Sedangkan pengaruh variabel lain di luar variabel yang dipergunakan diperoleh dengan mempergunakan rumus sebagai berikut :

$$
\begin{aligned}
& \rho_{\mathrm{Y} \varepsilon}=\sqrt{1-\mathrm{R}^{2} \mathrm{YX} 3} \\
& \rho_{Y \varepsilon}=\sqrt{1-0.354}=0.804
\end{aligned}
$$

Persamaan fungsi struktural untuk diagram jalur yang baru diperoleh:

$$
\mathrm{Y}=0.595 \mathrm{X} 3+\varepsilon
$$

Berdasarkan hasil pengolahan data analisis jalur baru diperoleh nilai signifikan $\mathrm{t}$ untuk variabel people $\left(\mathrm{X}_{3}\right)$ sebesar 5.129. Dengan mempergunakan tingkat signifikansi tidak lebih dari $\square=0,05$; maka diperoleh variabel people $\left(\mathrm{X}_{3}\right)$ berpengaruh terhadap sikap pembelian sehingga diperoleh diagram struktural yang baru, sebagai berikut: 


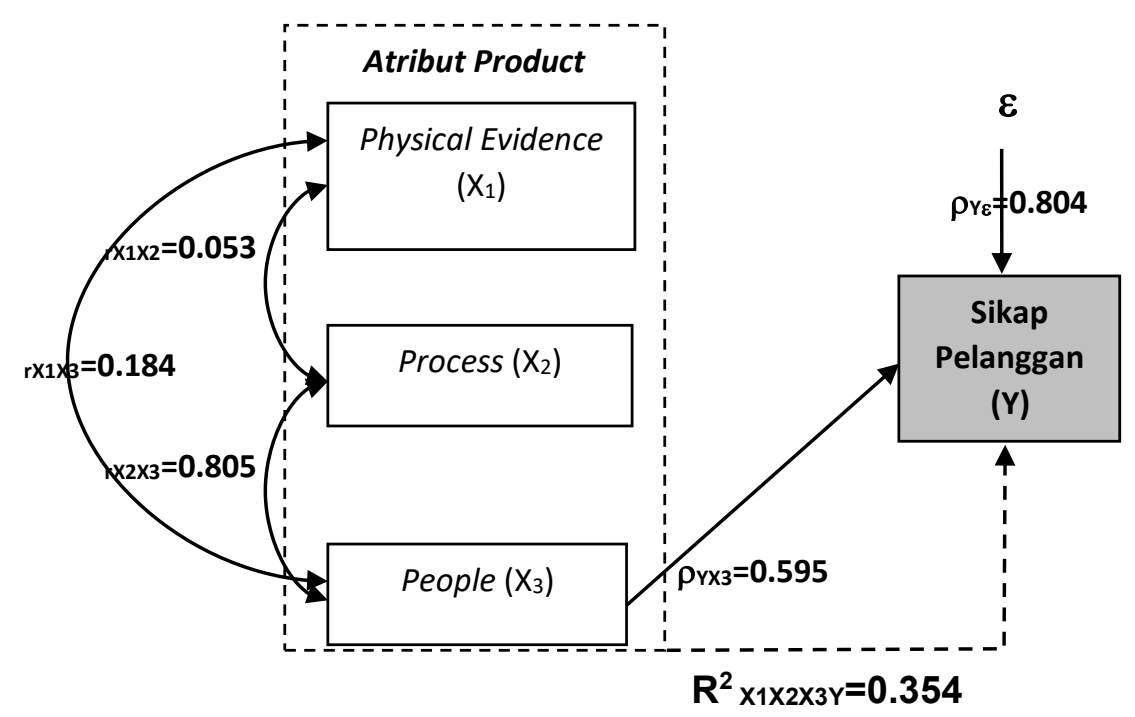

Gambar 5 Nilai koefisien jalur baru hubungan struktural

Sumber: Hasil Pengolahan Data

Berdasarkan hasil perhitungan antar variabel dengan nilai-nilai parameter struktural, maka pengaruh dari variabel penyebab ke variabel akibat baik yang bersifat langsung maupun tidak langsung dapat ditentukan, sebagai berikut:

a. Pengaruh langsung $\mathrm{X}_{3}$ terhadap $\mathrm{Y}$

$$
\begin{aligned}
\mathrm{Y} \longleftarrow \quad \mathrm{X}_{3} \longrightarrow \quad \mathrm{Y}=\rho_{\mathrm{YX} 3} \mathrm{X} \rho_{\mathrm{YX} 3} \quad \mathrm{x} 100 \% \\
=(0.595) \times(0.595) \times 100 \% \\
=35.40 \%
\end{aligned}
$$

b. Pengaruh Tidak Langsung $\mathrm{X}_{1}$ melalui $\mathrm{X}_{3}$ terhadap $\mathrm{Y}$

$$
\begin{aligned}
\mathrm{Y} \leftarrow \mathrm{X}_{1} \Omega \mathrm{X}_{3} \rightarrow \mathrm{Y} & =\rho^{2} \mathrm{YX}_{3} \times \mathrm{r}^{2} \mathrm{X}_{1} X_{3} \times 100 \% \\
& =(0.595)^{2} \times(0.184)^{2} \times 100 \% \\
& =1.20 \%
\end{aligned}
$$

c. Pengaruh Tidak Langsung $\mathrm{X}_{2}$ melalui $\mathrm{X}_{3}$ terhadap $\mathrm{Y}$

$$
\begin{aligned}
\mathrm{Y} \leftarrow \mathrm{X}_{2} \Omega \mathrm{X}_{3} \rightarrow \mathrm{Y} & =\rho^{2} \mathrm{YX}_{3} \times \mathrm{rr}^{2} \mathrm{X}_{2} X_{3} \times 100 \% \\
& =(0.595)^{2} \times(0.805)^{2} \times 100 \% \\
& =22.94 \%
\end{aligned}
$$


Atas dasar perhitungan tersebut dapat dikemukakan bahwa physical evidence $\left(\mathrm{X}_{1}\right)$ akan mempengaruhi perubahan sikap pembelian secara tidak langsung melalui variabel people $\left(\mathrm{X}_{3}\right)$ adalah sebesar $1.20 \%$, process $\left(\mathrm{X}_{2}\right)$ akan mempengaruhi perubahan sikap pembelian secara tidak langsung variabel people $\left(\mathrm{X}_{3}\right)$ adalah sebesar $22.94 \%$, people $\left(\mathrm{X}_{3}\right)$ akan mempengaruhi perubahan sikap pembelian secara langsung adalah sebesar $35.40 \%$.

Temuan penelitian menunjukan bahwa People (X3) memiliki kontribusi yang positif dan signifikan terhadap sikap pembelian. Artinya tinggi rendahnya kinerja people dalam jasa pelayanan corporate meeting di Hotel Malya Bandung dijelaskan oleh sikap pembelian. Besarnya kontribusi People $\left(\mathrm{X}_{3}\right)$ yang secara langsung berkontribusi terhadap sikap pembelian sebesar $35.40 \%$. Oleh karena itu untuk mengoptimalkan sikap pembelian harus diupayakan meningkatkan kinerja People.

Ditinjau dari sudut pandang hotel, pelayanan yang berkualitas akan dapat dipenuhi dengan memperhatikan kemampuan orang-orang (people) yang terlibat dalam pelaksanaan pelayanan tamu, pada perilaku atau kualitas manusianya serta tingkat ketrampilan atau keahlian yang dimiliki. Dua unsur utama yang membentuk pelayanan berkualitas, yaitu:

a. Kualitas manusia atau perilaku pribadi berkaitan dengan bagaimana karyawan memberikan pelayanan dengan menggunakan sikap, perilaku dan ketrampilan verbal berinteraksi dengan tamu. Menurut Erich Fromm (Sulastiyono, 2011) terdapat dua tipe manusia, yaitu yang selflove dan selfishness. Yang tergolong self-love hanya dapat mencintai kalau dia dapat diberi cinta termasuk kepada dirinya dan cinta kepada dirinya tak dapat dipisahkan dari cinta kepada sesama manusia. Selfishness bukan saja tidak dapat mencintai orang lain tetapi juga tida dapat mencintai dirinya sendiri. Jelas bahwa manusia yang selfish bukanlah kualitas manusia yang diperlukan untuk memberikan pelayanan, karena mereka akan merasa terpaksa untuk melayani dan dapat menimbulkan konflik nilai dalam dirinya sehingga menimbulkan frustasi yang agresif dan akan berpengaruh terhadap pelaksanaan pekerjaan dan mutu pelayanan. Untuk mudahnya, pada saat perekrutan karyawan, perlu untuk dilakukan test kepribadian yang dapat mengukur perilaku dan sikap calon karyawan.

b. Ketrampilan atau keahlian yaitu penguasaan terhadap unsur-unsur teknik dan prosedur serta sistem pelaksanaan pekerjaan yang mapan dalam mentransfer produk atau jasa. Untuk menciptakan pelayanan yang baik perlu adanya usaha pelatihan yang terus-menerus. Pelayanan sebagai suatu ketrampilan juga berarti merupakan suatu keahlian, artinya karyawan harus pandai dalam menjalankan tugasnya dan mampu menggunakan setiap jenis 
peralatan. Hal ini merupakan syarat mutlak untuk terciptanya pelayanan hotel yang lebih baik.

c. Pentingnya People didukung oleh hasil penelitian Kemp, Borders, Anaza dan Johnston bahwa meskipun pembelian organisasi pada umumnya adalah sangat logis, namun faktor emosi tetap mempengaruhi keputusan dan sikap pembelian (Elyria A. Kemp, 2018).

\section{PENUTUP}

\section{Kesimpulan}

Hasil analisis jalur persamaan fungsi struktural, diperoleh: $\mathrm{Y}=0.595 \mathrm{X}_{3}+\varepsilon$, dan koefisien determinasi diperoleh nilai $\mathrm{R}^{2} \mathrm{YX} 3=0.354$, sedangkan pengaruh variabel lain di luar variabel yang dipergunakan $\rho_{Y \varepsilon}=0.804$. Hal ini dapat disimpulkan bahwa pengaruh atribut produk terhadap sikap pembelian pelanggan bahwa hanya People $\left(\mathrm{X}_{3}\right)$ yang berpengaruh signifikan secara langsung terhadap sikap pembelian yaitu sebesar 35,40\%. Pengaruh Physical Evidence $\left(\mathrm{X}_{1}\right)$ dan Process $\left(\mathrm{X}_{2}\right)$ tidak berpengaruh signifikan terhadap sikap pembelian, namun berpengaruh tidak langsung melalui People $\left(\mathrm{X}_{3}\right)$ yaitu sebesar $24.14 \%$. Sedangkan pengaruh lain terhadap sikap pelanggan yang tidak dipergunakan dalam penelitian ini yaitu sebesar $40,46 \%$.

\section{Saran}

Penelitian ini diharapkan dapat memberikan masukan bagi pihak manajemen Hotel Malya Bandung untuk:

1. Mempertahankan serta lebih meningkatkan atribut product khususnya mengenai people yang sudah baik kinerjanya, hal ini dikarenakan atribut product khususnya mengenai people mempengaruhi secara langsung terhadap sikap pelanggan berdasarkan pandangan, keinginan untuk kembali menggunakan dan merekomendasikan Hotel Malya Bandung kepada orang lain.

2. Manajemen Hotel Malya Bandung diharapkan dapat menjaga konsistensi pelayanan melalui People (karyawan), dengan: memiliki standar kualifikasi perekrutan, memberikan pelatihan yang berkesinambungan, memberlakukan sistem reward \& recognation yang jelas, memberikan empowerment kepada staff yang berhadapan langsung dengan tamu. 
3. Selain itu, perlu pula ditelaah mengenai faktor-faktor lain yang cukup besar dalam pengaruhnya terhadap sikap pelanggan di Hotel Malya Bandung. Pembenahan ini harus dikaitkan dengan visi dan strategi perusahaan serta disesuaikan dengan kemampuan perusahaan, sehingga perusahaan harus mampu menentukan prioritas pembenahan.

\section{DAFTAR PUSTAKA}

Aritonang, L. R. (2005). Kepuasan pelanggan: pengukuran dan penganalisisan dengan SPSS. Jakarta: PT. Gramedia Pustaka Utama.

Bojanic, D. (2008). Handbook of hospitality marketing management. Amerika Serikat: Routledge.

Caplow, T. (2013). Psychological foundation of organisational behavioral. Glenview IL Scott, Foresman and Company.

Chambers, R., \& Lewis, L. R. (2015). Marketing leadership in hospitality : foundations and practices. New York; Chicheste: John Wiley \& Sons.

Elyria A. Kemp, A. L. (2018). The heart in organizational buying: marketers understanding of emotions and decision-making of buyers. Journal of Business and Industrial Marketing (33):1.

Gasperz, V. (2012). All in one management toolbook. Bogor: Tri-Al Bros Publishing.

Hoffman, K., \& Bateson, J. E. (2011). Service Marketing. South-Western College.

Jayawardhena, C. (2010). The Impact of Service Quality in Service Evaluation: Evidence

From a Business to Business Context. Journal of Business \& Industrial Marketing, Vol 25.

Jayawardhena, C., Souchon, A. L., \& Farrell Andrew M, G. K. (2007). Outcomes of Service Encounter Quality in a Business Context. Journal of Industrial Marketing Management, Vol. 36 .

Kotler, P., \& Armstrong, G. (2012). Principle of Marketing. New Jersey: Prentice.

Kotler, P., Bowen, J., Makens, J. C., \& Seyhmus, B. (2017). Marketing for Hospitality and Tourism. Harlow: Perarson.

Lovelock, C., \& Jochen, W. J. (2011). Services Marketing People Technology Strategy. Prentice Hall.

Mowen, J. C. (2008). Consumer behavior 5th Edition. Prentice-Hall.

Nadkarni, \& Leong, A. (2007). Macao's MICE dream: Opportunities and challenges. International journal of event management research, Vol 3, no. 2.

Palmer, A. (2014). Principles of services marketing. Maidenhead: McGraw-Hill Education.

Payne, A. (2013). The essence of service marketing. Andi Publisher. 
Peter, J. P., \& Jerry C, O. (2009). Consumer behavior and marketing strategy: Perilaku konsumen dan strategi pemasaran. Jakarta: Erlangga.

Peter, J. P., \& Olson, J. C. (2008). Consumer behavior and marketing strategy. Boston: McGraw-Hill/Irwin.

Ramdhani, N. (2008, April 3). Retrieved from Sikap dan beberapa definisi untuk memahaminya: http://neila.staff.ugm.ac.id.

Sekaran, U. (2014). Research Methods for Business, A Skill Building Approach. 6th Edition. Wiley.

Solomon, M. R. (2015). Consumer Behavior: Buying, Having, and Being. Pearson.

Sulastiyono, A. (2011). Manajemen Penyelenggaraan Hotel. Bandung: Alfabeta.

Sutisna. (2008). Perilaku Konsumen dan Komunikasi Pemasaran. Bandung: Remaja Rosdakarya.

Tanner, J. (2010). Marketing principles. Flatworld knowledge, inc.

Tjiptono, F. (2012). Pemasan strategik, edisi kedua. Yogyakarta: Andi offset.

Zeithaml V.A, M. B. (2013). Service Marketing: Integrating Customer Focus Accross The Firm. New York: McGraw-Hill Companies, Inc. 